\title{
Rete Testis Adenoma
}

National Cancer Institute

\section{Source}

National Cancer Institute. Rete Testis Adenoma. NCI Thesaurus. Code C39956.

A benign epithelial neoplasm arising from the rete testis. 